\title{
Edible Coatings for Lightly Processed Fruits and Vegetables
}

\author{
E.A. Baldwin ${ }^{1}$ \\ Agricultural Research Service, U.S. Department of Agriculture, Citrus and Subtropical Products Laboratory, \\ Winter Haven, FL 33883 \\ M.O. Nisperos-Carriedo \\ Food Research Institute, Department of Agriculture, Werribee, Victoria, Australia \\ R.A. Baker ${ }^{1}$ \\ Agricultural Research Service, U.S. Department of Agriculture, Citrus and Subtropical Products Laboratory, \\ Winter Haven, FL 33883
}

\begin{abstract}
The increased health consciousness of consumers, diminished food preparation times, and increased purchasing power have recently combined to increase the demand for minimally processed fruits and vegetables. Minimal or light processing of fruits and vegetables describes processing steps such as trimming, peeling, sectioning, slicing, and coring. According to some reports, $25 \%$ to $80 \%$ of harvested fresh fruits and vegetables may be lost due to spoilage worldwide (Wills et al., 1981). Lightly processed produce (LPP) has a greatly reduced shelf life compared to whole fruits and vegetables, in part due to the deteriorative physiological changes that occur in what is essentially wounded viable tissue. Edible coatings offer a possible method of extending postharvest storage life for this type of commodity. Fresh, minimally processed produce can be enrobed in these edible materials, providing a semipermeable barrier to gases and water vapor. Such coatings can reduce respiration and water loss, and be used as carriers of preservatives and antioxidants.
\end{abstract}

\section{EDIBLE COATING THEORY AND TECHNOLOGY}

\section{Materials}

Use of coatings for fruits and vegetables is not a new concept and, in fact, dates back to the 12th and 13th centuries (Hardenburg, 1967). Edible coatings are generally made from one or more of four major types of materials: lipids, resins, polysaccharides, and proteins. In addition, plasticizers, such as polyhydric alcohols, waxes, and oils, are added to improve flexibility and elongation of polymeric substances (Andres, 1984; Chuah et al., 1983; Cole, 1969; Gennadios and Weller, 1990; Jokay et al., 1967; Schultz et al., 1949). Addition of surfaceactive agents (surfactants) and emulsifiers reduces superficial water activity and rate of moisture loss in food products (Roth and Loncin, 1984). Release agents and lubricants are added to prevent coated food products from sticking. These can include fats and oils, emulsifiers, petrolatum, polyethylene glycol, and silicone. The following section presents some specific examples from the four classes of materials used as major ingredients in edible coatings.

Lipids. Lipid-based coatings are made from waxes and oils, such as paraffin wax or oil, beeswax, carnauba wax, candelilla wax, mineral oil, vegetable oil, acetylated monoglycerides, stearic acid, lauric acid, or sucrose esters of fatty acids. These coatings are generally effective barriers to moisture, while those containing resins (shellac, wood rosin, coumarone-indene resin) are more permeable to water vapor than lipids, but less so than some polysaccharide coatings (Hagenmaier and Shaw, 1990). These materials have been used extensively on whole fruits and vegetables. Some lipid and most resin coatings, however, can cause anaerobic conditions at higher storage temperatures due to low gas-permeability characteristics (Hagenmaier and Shaw, 1992), and they do not adhere to hydrophilic cut surfaces. Lipids made from animal products (tallow, for example) may raise concerns

Mention of a trademark or proprietary product is for identification only and does not imply a guarantee or warranty of the product by the U.S. Dept. of Agriculture.

${ }^{1}$ South Atlantic Area, Agricultural Research Service, U.S. Dept. of Agriculture. on the part of certain religious organizations or strict vegetarians when used on fruits and vegetables. Of the lipid materials mentioned above, beeswax, acetylated monoglycerides, stearic acid, lauric acid, and sucrose fatty acid esters have appeared in edible-coating formulations designed for LPP (Avena-Bustillos et al., 1994, unpublished; AvenaBustillos and Krochta, 1993; Pennisi, 1992; Sakane et al., 1990; Wong et al., 1994).

Polysaccharides. Coatings made of polysaccharides (cellulose, pectin, starch, alginates, chitosan, carrageenan, gums) are generally good gas barriers and adhere well to cut surfaces of fruits or vegetables, but their hydrophilic nature makes them poor barriers to moisture (Kester and Fennema, 1988; Swenson et al., 1953). Chitosan (a deacetylated form of chitin) inhibits the growth of several fungi (Allan and Hadwiger, 1979; Hirano and Nagao, 1989; Stossel and Leuba, 1984). Approval of chitosan as a food additive is still pending in the United States, but its acceptance is considered only a matter of time. Of the polysaccharide materials, cellulose- and chitosan-based coatings have shown some promise for extending shelf life of LPP (Pennisi, 1992; Sargent et al., 1995).

Proteins. Proteins (casein, gelatin, soy, zein, egg albumen, etc.) are good film-formers and will adhere to hydrophilic surfaces, but, in most cases, they do not resist water vapor diffusion (Rendell-Dunn, 1990; Gennadios and Weller, 1990). As mentioned in the discussion of lipid materials, proteins that are made from animal products (casein, gelatin, and egg albumen) may raise issues for certain consumer groups. Some casein-containing coatings have improved the quality of certain LPP. Protein components used in formulations for LPP include casein and soy protein (Avena-Bustillos et al., 1993, 1994, unpublished; Kinzel, 1992; Wong et al., 1994).

In light of the advantages and disadvantages of the various coating components, many formulations cited in the recent literature have been comprised of differing combinations of the above materials. In these composite or bilayer coatings, two or more materials from the above groups are combined or layered to improve gas exchange, adherence, and moisture vapor permeability properties. For example, composite coatings of chitosan and some higher boiling acids resulted in a chitosan-fatty acid salt. The water transmission of such films depended on the hydrophobicity of the fatty acid chain. Of the possible fatty acids tested, the chitosan-lauric acid film resulted in a unique film structure (overlapping platelets) that improved the water resistance property of the coating (Wong et al., 1992). Similar results were observed by Kester and Fennema (1989) in a study of lipid resistance to water vapor transmission. The gas diffusion rate was not affected as much by the film's hydrophobicity. Such films hold promise for coating whole or lightly processed agricultural products.

\section{Incorporating food additives}

Coatings can serve as carriers of ingredients that perform a specific function that is separate from general coating performance (barrier properties, etc.). For example, on whole citrus fruit and peaches, edible coatings have often served as carriers of antimicrobial agents such as fungicides (Brown, 1974, 1984; Wells, 1971). For minimally processed fruits and vegetables, preservatives can be incorporated to 
retard surface growth of yeasts, molds, and bacteria during storage and distribution. Antimicrobials that may be used in various food systems include benzoic acid, sodium benzoate, sorbic acid, potassium sorbate, and propionic acid. Slow diffusion of the preservative into the food mass and concomitant reduction of surface concentrations diminishes its effectiveness over time (Giannakopoulos and Guilbert, 1986a, 1986b; Torres et al., 1985a, 1985b). Coatings can help hold the preservative on the cut fruit surface where it is needed. Extensive studies in model food systems have defined the effectiveness of edible films in controlling diffusion of preservatives, such as sorbic acid and potassium sorbate (Giannakopoulos and Guilbert, 1986a, 1986b; Guilbert, 1988; Guilbert et al., 1985; Torres, 1987; Torres and Karel, 1985; Vojdani and Torres, 1990, 1989). The coating efficiencies showed that carnauba wax containing sorbic acid was the best one in maintaining microbial stability (presumably by controlling surface preservative concentration), followed by carnauba wax alone. Similarly, the casein coating containing sorbic acid was superior to casein alone.

Another example of useful additives to coatings are antioxidants. These compounds are added to edible coatings to protect against oxidative rancidity, degradation, and discoloration. Certain phenolic compounds [butylated hydroxyanisole (BHA), butylated hydroxytoluene (BHT), or tertiary butylated hydroxyquinone], tocopherols, or acids such as propyl gallate have antioxidant properties and inhibit oxidation of fats and oils in foods. There is also a synergistic effect between polyphenolic compounds and certain acidic substances, such as ascorbic, citric, and phosphoric acid, which are effective chelating agents. Ethylene diaminetetraacetic acid and its salts are also widely used as metal chelators in food systems (Stucky, 1972). For example, nuts were coated with pectinate, pectate, and zein coatings containing BHA, BHT, and citric acid to prevent rancidity and maintain texture (Andres, 1984; Swenson et al., 1953). Edible coatings reduced enzymatic browning in whole and sliced mushrooms [Agaricus bisporus (J.E. Lange) Imbach], especially with the incorporation of an antioxidant and a chelator (ascorbic acid, calcium disodium ethylenediamine tetraacetic acid) (Nisperos-Carriedo et al., 1991).

Calcium chloride may be incorporated in coatings to improve the texture and color of food products. Certain coatings, such as those of alginate and low-methoxyl pectin, use solutions of calcium chloride to induce gelation of the coatings (Earle, 1968; Miers et al., 1953; Swenson et al., 1953).

\section{Modifying the internal atmosphere}

The ideal edible coating should create a barrier that can retard loss of desirable flavor volatiles and water vapor, while restricting the exchange of $\mathrm{CO}_{2}$ and $\mathrm{O}_{2}$, thus creating a modified atmosphere (MA) (relatively elevated $\mathrm{CO}_{2}$ and reduced $\mathrm{O}_{2}$ ). Such a MA would slow down respiration and ethylene production and inhibit ethylene action (elevated $\mathrm{CO}_{2}$ ) (Sisler and Wood, 1988). The MA created by the coatings should not, however, create anaerobic conditions that could cause anaerobic respiration, undesirable flavor changes, and growth of anaerobic microbes. Of course, in reality, this is difficult to accomplish. Many of the early waxes on whole fruits reduced permeability to $\mathrm{O}_{2}$ and $\mathrm{CO}_{2}$, resulting in increased internal $\mathrm{CO}_{2}$, decreased internal $\mathrm{O}_{2}$ (Nisperos-Carriedo et al., 1990; Smock, 1935; Trout et al., 1942), and higher concentrations of flavor volatiles (both desirable and objectionable) (Nisperos-Carriedo et al., 1990). The high respiration, ethylene production, and moisture loss resulting from processing also can, theoretically, be reduced by applying a semipermeable membrane, such as an edible coating.

Temperature and relative humidity conditions can affect coating properties and performance. Gas barrier properties of edible coatings depend on the relative humidity $(\mathrm{RH})$ at which coated produce is stored. When under high $\mathrm{RH}$, the more hydrophilic coatings, for example, may incorporate water into the film structure, which may increase their permeability to gases (Hauser and McLaren, 1948; McHugh and Krochta, 1994). Coating permeability characteristics and behavior may be especially difficult to predict on a cut surface where RH is high. Respiration rates increase significantly with an increase in storage temperature. In other words, a coating, plastic packaging, or both that created the appropriate MA for a product stored at a low temperature can cause anaerobic conditions if the product is under an elevated temperature for an extended period.

Predictions of gas and water barrier properties of coatings assume continuity of the coating, which is not always the case. This is especially true for cut horticultural produce, where cellular contents have washed over the surface, which can result in discontinuous coverage of applied coatings. Theoretically, coatings that are applied to a wet cut surface may be diluted by surface moisture or wicked away by capillary action, preventing continuous, uniform coverage. Drying such coatings, when necessary, can result in moisture loss from the coated fruit tissue, defeating the purpose of coating such produce. In contrast, hydrophilic coatings can sometimes serve as a sacrificing agent, giving up water within the coating before water is lost from the coated product, thus delaying water loss of the coated product (Kester and Fennema, 1986).

\section{EDIBLE COATING APPLICATIONS FOR LIGHTLY PROCESSED FRUITS AND VEGETABLES}

Use of edible coatings for lightly processed fresh produce is mostly in experimental stages. Research results either are preliminary, in press, or published within the past few years. The following is a summary of what has been reported in the literature, as well as advance information from reports that are not yet published.

\section{Apples}

A soybean [Glycine $\max ($ L.) Merr.] coating, developed at the U.S. Dept. of Agriculture (USDA), Agricultural Research Service, preserved freshness of apple (Malus domestica Borkh.) slices in preliminary studies (Kinzel, 1992). Browning and water loss of cut apple slices has been inhibited by a composite coating of chitosan and lauric acid (Pennisi, 1992). A casein (milk protein) and lipid (acetylated monoglyceride, stearate, or beeswax) mixture was developed for lightly processed fruits and vegetables. It protected a processed piece of apple from moisture loss and oxidative browning for up to 3 days. Incorporating beeswax into a sodium caseinate film was more effective in reducing water vapor permeability than stearic acid or acetylated monoglyceride, perhaps due to the crystalline structure of beeswax films. Calcium ion crosslinking also reduced water vapor permeability of sodium caseinate films, probably as a result of reduced protein polymer segmental mobility and protein solubility in water (Avena-Bustillos and Krochta, 1993).

A composite coating of alginic acid (polysaccharide polymer of mannosyluronic and gulosyluronic acid, which contains carboxyl groups), casein (milk protein), and lipid (acetylated monoglyceride) that crosslinks with the addition of calcium ions into a three-dimensional network was developed by the USDA. The casein protein is contained in the cross-linked polysaccharide matrix, with the acetylated monoglyceride dispersed in the interstices. This type of coating may also crosslink with the carboxyl groups of the endemic pectin on the cut surface of the fruit or vegetable if the cut piece is first dipped into a solution containing calcium. This linking would be especially likely for cut apple slices that are high in pectin. This coating reportedly reduced water loss and browning of cut apple (Wong et al., 1994).

A bilayer coating of polysaccharide and lipid increased water vapor resistance in cut apple by $92 \%$, decreased respiration by $70 \%$, and ethylene evolution by $90 \%$ (23C, 50\% RH) (Wong et al., 1994).

\section{Carrots}

Minimally processed carrots (Daucus carota L.) are a ready-to-eat product with a limited shelf life due to a physiological disorder known as "white blush." Formation of the whitish appearance on the surface of peeled carrots has been attributed to dehydration (Tatsumi et al., 1991) and possibly lignin formation in response to peeling (Bolin and Huxsoll, 1991). White blush of peeled carrots is generally determined using a color meter and a whiteness index. A sodium caseinate/stearic acid emulsion reduced white blush of peeled carrot sections (whiteness index for uncoated was 48 vs. 42 for coated after 15 days at 10C) 
and respiration rate $(4.75 \mathrm{ml} \mathrm{CO} / \mathrm{kg}$ per hour in uncoated and 3.74 for coated after 30 days at 2.5C) (Avena-Bustillos et al., 1994). Reduced white blush was due to the increased vapor resistance provided by this coating (Avena-Bustillos et al., 1993). A cellulose-based coating, called Nature-Seal (Nisperos-Carriedo and Baldwin, 1993), significantly reduced white blush on peeled carrots for up to 1 month at $4 \mathrm{C}$ (Sargent et al., 1995).

\section{Celery}

A casein-acetylated monoglyceride coating, similar to the one described above for carrots, significantly $(75 \%)$ reduced moisture loss in celery sticks (Apium graveolens L.) (Avena-Bustillos et al., unpublished). This coating did not, however, modify respiration or ethylene production of coated apples or celery sticks. Apparently, the coating was sufficiently permeable to gases such that the internal atmosphere of the tissue was not altered to the point of affecting respiration or ethylene production.

\section{Cabbage}

Shredded cabbage (Brassica oleracea L. Captitata Group) was dipped in sucrose fatty acid esters $(0.25 \%)$. Browning was reduced in cabbage after storage at $10 \mathrm{C}$, apparently due to reduced $\mathrm{O}_{2}$ at the cabbage surface, and also to increased ethanol concentrations (Sakane et al., 1990).

\section{FUTURE RESEARCH}

Research is needed to combine the desirable gas permeability and textural benefits of polysaccharide and protein coatings with better water barrier properties associated with lipid components. Solubility of polysaccharide polymers, such as cellulose, starch, or chitin, requires hydrolysis, derivatization, or both. The size of the polymer, or type of salts and functional groups added, result in different permeability properties. Properties of proteins also can be manipulated by adding various functional groups to improve solubility, water resistance, etc. Soy protein, for example, significantly improved solubility and emulsifying activity over a lower $\mathrm{pH}$ range upon phosphorylation by a protein kinase (Campbell et al., 1992). The interaction of proteins, polysaccharides, and lipids in coatings and the interaction between coatings and plastic packaging needs to be explored further for successful commercialization of this technology.

\section{Literature Cited}

Allan, C.R. and L.A. Hadwiger. 1979. The fungicidal effect of chitosan on fungi of varying cell wall composition. Expt. Mycology 3:285-287.

Andres, C. 1984. Natural edible coating has excellent moisture and grease barrier properties. Food Processing Dec:48-49.

Avena-Bustillos, R.J. and J.M. Krochta. 1993. Water vapor permeability of caseinate-based edible films as affected by $\mathrm{pH}$, calcium crosslinking and lipid content. J. Food Sci. 58:904-907.

Avena-Bustillos, R.A., L.A. Cisneros-Zevallos, and J.M. Krochta. 1993. Optimization of edible coatings on minimally processed carrots to reduce white blush using response surface methodology. Trans. Amer. Soc. Agr. Eng. 36:801-805.

Avena-Bustillos, R.A., L.A. Cisneros-Zevallos, and J.M. Krochta. 1994. Application of casein-lipid edible film emulsions to reduce white blush on minimally processed carrots. Postharvest Biol. \& Technol. 4:319-329.

Bolin, H.R. and C.C. Huxsoll. 1991. Control of minimally processed carrot (Daucus carota) surface discoloration caused by abrasion peeling. J. Food Sci. 56:416-418.

Brown, E. 1984. Efficacy of citrus postharvest fungicides applied in water or resin solution water wax. Plant Dis. 68:415-418.

Brown, G.E. 1974. Benomyl residues in Valencia oranges from postharvest applications containing emulsified oil. Phytopathology 64:539-542.

Campbell, N.F., F.F. Shih, and W.E. Marshall. 1992. Enzymatic phosphorylation of soy protein isolate for improved functional properties. J Agr. Food Chem. 40:403-406.

Chuah, E.C., A.Z. Idrus, C.L. Lim, and C.C. Seow. 1983. Development of an improved soya protein-lipid film. J. Food Technol. 18:619-627.

Cole, M.S. U.S. patent 3,479,191. 18 Nov. 1969.

Earle, R.D. U.S. patent 3,395,024. 30 July 1968
Gennadios, A. and C.L. Weller. 1990. Edible films and coatings from wheat and corn proteins. Food Technol. 44(10):63-69.

Giannakopoulos, A. and S. Guilbert. 1986a. Determination of sorbic acid diffusivity in model food systems. J. Food Technol. 21:339-353.

Giannakopoulos, A. and S. Guilbert. 1986b. Sorbic acid diffusivity in relation to the composition of high and intermediate moisture model gels and foods. J. Food Technol. 21:477-485.

Guilbert, S. 1988. Use of superficial edible layer to protect intermediate moisture foods: Application to the protection of tropical fruit dehydrated by osmosis, p. 199-219. In: C.C. Seow (ed.). Food preservation by moisture control. Elsevier Applied Science Publishers, London.

Guilbert, S., A. Giannakopoulos, and J.C. Cheftel. 1985. Diffusivity of sorbic acid in food gels at high and intermediate water activities, p. 343-356. In: D. Simatos and J.L. Multon (eds.). Properties of water in foods. Martinus Nijhoff Publishers, Dordrecht, Netherlands.

Hagenmaier, R.D. and P.E. Shaw. 1990. Moisture permeability of edible films made with fatty acid and (hydroxypropyl) methylcellulose. J. Agr. Food Chem. 38:1799-1803.

Hagenmaier, R.D. and P.E. Shaw. 1992. Gas permeability of fruit coating waxes. J. Amer. Soc. Hort. Sci. 117:105-109.

Hardenburg, R.E. 1967. Wax and related coatings for horticultural products. A bibliography. Agr. Res. Bul. 51-15, U.S. Dept. of Agr., Washington, D.C.

Hauser, P.M. and A.D. McLaren. 1948. Permeation through and sorption of water vapor by high polymers. Industrial Eng. Chem. 40:112-117.

Hirano, S. and N. Nagao. 1989. Effects of chitosan, pectic acid, lysozyme, and chitinase on the growth of several phytopathogens. Agr. Biol. Chem. 53:3065-3066.

Jokay, L., G.E. Nelson, and E.C. Powell. 1967. Amylaceous coatings for foods Food Technol. 21:1064-1066.

Kester, J.J. and O.R. Fennema. 1986. Edible films and coatings: A review. Food Technol. 40:47-59.

Kester, J.J. and O.R. Fennema. 1988. Edible films and coatings: A review. Food Technol. 42:47-59.

Kester, J.J. and O.R. Fennema. 1989. Resistance of lipid films to water vapor transmission. J. Amer. Oil Chem. Soc. 66:1139-1146.

Kinzel, B. 1992. Protein-rich edible coatings for food. Agr. Res. May:20-21.

McHugh, T.H. and J.M. Krochta. 1994. Permeability properties of edible films, p. 139-187. In: J.M. Krochta, E.A. Baldwin, and M.O. Nisperos-Carriedo (eds.). Edible coatings and films to improve food quality. Technomic Publishing Co., Lancaster, Pa.

Miers, J.C., H.A. Swenson, T.H. Schultz, and H.S. Owens. 1953. Pectinate and pectate coatings. I. General requirements and procedures. Food Technol. 7:229-231.

Nisperos-Carriedo, M.O. and E.A. Baldwin. U.S. Patent 7,679,849. 9 Sept. 1993.

Nisperos-Carriedo, M.O., E.A. Baldwin, and P.E. Shaw. 1991. Development of an edible coating for extending postharvest life of selected fruits and vegetables. Proc. Fla. State Hort. Soc. 104:122-125.

Nisperos-Carriedo, M.O., P.E. Shaw, and E.A. Baldwin. 1990. Changes in volatile flavor components of pineapple orange juice as influenced by the application of lipid and composite film. J. Agr. Food Chem. 38:1382-1387.

Pennisi, E. 1992. Sealed in edible film. Sci. News 141:12.

Rendell-Dunn, A.J. 1990. General news: Protein films from maize, wheat and soybeans-Will they extend fruit and vegetable shelf life. Postharvest News \& Info. 1:435.

Roth, T. and M. Loncin. 1984. Superficial activity of water, p. 433-443. In: B.M. McKenna (ed.). Engineering and food. vol. 1. Elsevier Applied Science Publishers, London.

Sakane, Y., N. Arita, S. Shimokana, H. Ito, and Y. Osajima. 1990. Storage of shredded cabbage in plastic films using ethylene-acetaldehyde or sucrose fatty acid esters (English summary). Nippon Shokuhin Kogyo Gakkaishi 37:281-286.

Sargent, S.A., J.K. Brecht, J.J. Zoellner, E.A. Baldwin, and C.A. Campbell. 1995. Edible films reduce surface drying of peeled carrots. Proc. Fla. State Hort. Soc. (In press.)

Schultz, T.H., J.C. Miers, H.S. Owens, and W.D. Maclay. 1949. Permeability of pectinate films to water vapor. J. Physical Chem. 53:1320-1330.

Sisler, E.C. and C. Wood. 1988. Interaction of ethylene and $\mathrm{CO}_{2}$. Physiol. Plant. 73:440-444.

Smock, R.M. 1935. Certain effects of wax treatments on various varieties of apples and pears. Proc. Amer. Soc. Hort. Sci. 33:284-289.

Stossel, P. and J.C. Leuba. 1984. Effect of chitosan, chitin and some amino sugars on growth of various soilborne phytopathogenic fungi. Phytopathol. Z. 111:82-90.

Stucky, B.N. 1972. Antioxidants as food stabilizers, p. 185-225. In: T.E. Furia (ed.). CRC handbook of food additives. vol. I. CRC Press, Boca Raton, Fla.

Swenson, H.A., J.C. Miers, T.H. Schultz, and H.S. Owens. 1953. Pectinate and pectate coatings. II. Application to nut and fruit products. Food Technol. 7:232-235 
Tatsumi, Y., A.E. Watada, and W.P. Wergin. 1991. Scanning electron microscopy of carrot stick surface to determine cause of white translucent appearance. J. Food Sci. 56:1357-1359.

Torres, J.A. 1987. Microbial stabilization of intermediate moisture food surfaces, p. 329-368. In: L.B. Rockland and L.R. Beuchat (eds.). Water activity: Theory and applications to food. Marcel Dekker, New York.

Torres, J.A. and M. Karel. 1985. Microbial stabilization of intermediate moisture food surfaces. III. Effects of surface preservative concentration and surface $\mathrm{pH}$ control on microbial stability of an intermediate moisture cheese analog. J. Food Processing Preservation 9:107-119.

Torres, J.A., J.O. Bouzas, and M. Karel. 1985a. Microbial stabilization of intermediate moisture food surfaces. II. Control of surface pH. J. Food Processing Preservation 9:93-106.

Torres, J.A., M. Motoki, and M. Karel. 1985b. Microbial stabilization of intermediate moisture food surfaces. I. Control of surface preservative concentration. J. Food Processing Preservation 9:75-92.

Trout, S.H., E.G. Hall, R.N. Robertson, F.M.V. Hackney, and S.M. Sykes. 1942. Studies in the metabolism of apples. I. Preliminary investigations on internal gas composition and its relation to changes in stored Granny Smith apples. Austral. J. Expt. Biol. Med. Sci. 20:219-231.

Vojdani, F. and J.A. Torres. 1990. Potassium sorbate permeability of methyl- cellulose and hydroxypropyl methylcellulose coatings: Effects of fatty acids. J. Food Sci. 55:841-846.

Vojdani, F. and J.A. Torres. 1989. Potassium sorbate permeability of polysaccharide films, chitosan, methylcellulose and hydroxypropyl methylcellulose. J. Food Processing Eng. 12:33-48.

Wells, J.M. 1971. Heated wax-emulsions with benomyl and 2,6-dichloro-4nitroaniline for control of postharvest decay of peaches and nectarines. Phytopathology 62:129-133.

Wills, R.H., T.H. Lee, D. Graham, W.B. McGlasson, and E.G. Hall. 1981. Postharvest, an introduction to the physiology and handling of fruits and vegetables. AVI, Westport, Conn.

Wong, D.W.S., W.M. Camirand, and A.E. Pavlath. 1994. Development of edible coatings for minimally processed fruits and vegetables, p. 65-88. In: J.M. Krochta, E.A. Baldwin, and M.O. Nisperos-Carriedo (eds.). Edible coatings and films to improve food quality. Technomic Publishing Co., Lancaster, Pa.

Wong, D.W.S., F.A. Gastineau, K.S. Gregorski, S.J. Tillin, and A.E. Pavlath. 1992. Chitosan-lipid films: Microstructure and surface energy. J. Agr. Food Chem. 40:540-544.

Wong, D.W.S., S.J. Tillin, J.S. Hudson, and A.E. Pavlath. 1994. Gas exchange in cut apples with bilayer coatings. J. Agr. Food Chem. 42:2278-2285.

\title{
Selection of Cultivars for Lightly Processed Fruits and Vegetables
}

\author{
William R. Romig 1 \\ DNA Plant Technology Corporation, 2611 Branch Pike, Cinnaminson, NJ 08077
}

Some retail economists have projected that as much as $50 \%$ of the dollar volume generated by the supermarket produce department will come from fresh-cut fruits and vegetables by the end of the century (Graziano, 1993). To provide high-quality, value-added products throughout the year will require superior raw material and the optimization of all postharvest steps. Fruit and vegetable cultivars are routinely screened and selected for specific functional properties. Processors of lightly processed fruits and vegetables have selected those cultivars that, when evaluated under current cultural, postharvest, and distribution practices, meet their economic needs and the general specifications of the intended product. Although the trade and the consumer have provided incentives for such convenience products, no cultivar has been deliberately developed with the process and distribution in mind.

Microbiologists have revealed the potential sanitation problems associated with lightly processed produce (LPP). To combat this hazard, processors are implementing Hazard Analysis of Critical Control Points (HACCP) protocols (Bryan, 1988). HACCP identifies all steps in the process that can contribute to increased incidence of microbial growth (and loss of quality) and implements protocols at each step to monitor key elements and minimize quality deterioration. The status of the raw material and hence the characteristics of the selected cultivar greatly impact the microbial population by its degree of resistance or particular substrate availability and response to stress conditions. Pseudomonas spp. and Erwinia spp. can become significant problems, or weak and opportunistic organisms, such as Leuconostoc, can become problematic, especially in extended-shelflife products. Therefore, cultivar selection, preharvest cultural practices, postharvest handling, and grading raw material are interactive and their optimization is crucial to routinely producing quality products.

There are several types of latent damage, the extent of which is determined by the interaction of the genotype with its cultural and postharvest environment. Bruising is the most common latent damage, as impact can occur at any point in the process, but tissue breakdown or discoloration becomes noticeable later. For example, potatoes

'Current address: EPL Technologies, 200 Four Falls Corporate Center, Suite 315, Conshohocken, PA 19428.
(Solanum tuberosum $\mathrm{L}$.) begin to discolor in $\approx 4 \mathrm{~h}$ after initial impact (Belknap et al., 1990). Exocarp thickness, fruit shape, turgidity, etc., will affect the physical damage incurred during processing. Harvest maturity of the individual cultivar is another important factor that affects processing and product quality (Shewfelt, 1993). A variety of disorders can result from preharvest and postharvest stress conditions. Nutrition and soil conditions greatly impact the quality of root crops, such as carrots (Daucus carota L.). Heavy soils, poor nutritional balance, and moisture conditions cause abnormal root growth of carrots that can lead to various degrees of latent damage, depending on the cultivar. Postharvest desiccation or increased temperatures of the raw material during transit will affect the processing and final product quality, with carrot varying in its susceptibility to such stress conditions (unpublished). Under stress conditions, produce is commonly stored and transported under refrigeration to repress metabolism and desiccation, and maintain harvest quality (Uritani, 1978). Quiescent infection, where the organism has infected fruits and vegetables before harvest but remains quiescent until after harvest or processing, when stress conditions provide favorable growth conditions, is another example of latent damage (Wills et al., 1989). The extent of infection and microbial growth after harvest depends on cultivar resistance and its interaction with environmental factors.

\section{Lightly (minimally) processed fruits and vegetables}

Since the mid-1980s, there has been an increasing amount of activity in this area, with individuals applying various working definitions, depending on their research or specific goals. Huxoll and Bolin (1989) stated that "Minimally processed fruits and vegetables are products that have the attributes of convenience and fresh like quality." They go on to say something even more critical. "For minimal processed foods, processing and distribution are accomplished in a highly integrated system." To maintain a focus on providing a consumer product, the definition of minimal processing is extended to processing that, when combined with the optimization of all other steps of production, preparation, and distribution of produce to the consumer, will yield products of extended shelf life with fresh-like quality. This process starts with the selection/development of the most suitable variety. 